\title{
"MINHA HISTÓRIA VERDADEIRA SOBRE FANTASMAS": A TEORIA PÓS-COLONIALISTA E O GÓTICO EM RUDYARD KIPLING E HUGO DE CARVALHO RAMOS
}

\section{"MY OWN TRUE GHOST STORY": THE POSTCOLONIAL THEORY AND THE GOTHIC IN RUDYARD KIPLING AND HUGO DE CARVALHO RAMOS}

\author{
Fabianna Simão Bellizzi Carneiro ${ }^{1}$
}

Vivo ou morto - não há outra alternativa. (Provérbio indiano)

\begin{abstract}
RESUMO: Guardadas as devidas especificidades de cada produção, o período de publicação, a formação do escritor, faz-se uma leitura comparativa dos contos "Minha história verdadeira sobre fantasmas", do escritor hindu-americano Rudyard Kipling; e "A madre de ouro", do brasileiro Hugo de Carvalho Ramos (publicados respectivamente e inicialmente em 1888 e 1917) à luz das teorias pós-colonialistas, e ainda alinhavadas por manifestações do maquinário gótico europeu oitocentista, comprovando-se a hipótese de que o arsenal de crenças e superstições perfaz instrumento desestabilizador do poder imperial. Dentro desse quadro, objetiva-se analisar como o espaço das colônias torna-se fértil para se pesquisar a manifestação do gótico local em diálogo com a tradição gótica imperialista.
\end{abstract}

PALAVRAS-CHAVE: Pós-colonialismo; gótico imperialista; Rudyard Kipling, Hugo de Carvalho Ramos

ABSTRACT: Given the rightfully attibutions of each literary work, its period of publication, the writer's development, it's intended a comparative reading of the tales: "My own true ghost story", by the hindu american Rudyard Kipling; and "A madre de ouro", by the brazilian Hugo de Carvalho Ramos (published respectively and initially in 1888 and 1917) in the light of the postcolonial theories and also lined by manifestations of the nineteenth century european gothic machinery, proving the hypothesis that the arsenal of beliefs and superstitions make up the destabilising instrument of imperial power. Within that framework, it's aimed an analysis on how the space of the colonies becomes fertile to search the local gothic manifestation in dialogue with the imperialist gothic tradition.

KEYWORDS: Postcolonialism; imperialist gothic; Rudyard Kipling, Hugo de Carvalho Ramos

\footnotetext{
${ }^{1}$ Doutora em Literatura Comparada pela UERJ. Professora da Unidade Acadêmica de Letras e Linguística da Universidade Federal de Goiás_Universidade Federal de Catalão (em transição) e docente do PPG em Estudos da Linguagem.
} 


\section{Notas introdutórias}

Thomas Bonnici (2003), em "Teoria e crítica pós-colonialistas", pontua que a teoria pós-colonialista constitui uma nova estética a interpretar textos centrada na íntima relação entre discurso e poder. Embora tal colocação nos seja familiar (lembremos que as dinâmicas iniciais que levaram países europeus em busca de riquezas e mão de obra nos espaços colonizados pautaram-se em discursos que classificavam o espaço receptor das embarcações europeias como inferior, selvagem, local "a ser dominado"), a teoria pós-colonialista é recente - se quisermos buscar um marco cronológico, podemos situá-la no bojo dos Estudos Culturais. Por volta de 1960 e através de práticas analíticas interdisciplinares, estudiosos passam a questionar determinadas formas de produção enraizadas em posturas, ideias e abordagens unilaterais há muito cristalizadas (HATTNHER, 2003). Por ação dos Estudos Culturais podemos, por exemplo, efetuar a leitura de uma obra como A escrava Isaura (1875) a partir da teoria póscolonialista, muito embora os horrores e desmandos cometidos pelo sistema colonial estejam bem deslindados pelo autor da obra, Bernardo Guimarães. Hoje podemos ler a obra de Guimarães e tantas outras narrativas a partir das concepções pós-colonialistas não só porque nos distanciamos desse período, e essa distância nos permite melhor compreensão dos arquivos de uma época que não é nossa, mas por conseguirmos esmiuçar as falas de poder que prevaleceram (e ainda prevalecem) em muitas construções discursivas que tendem a manter o "outro" (leia-se outro diferente de um padrão hegemônico construído) em um lugar subalterno, afinal "as raízes do imperialismo são muito mais profundas e extensas" (BONNICI, 1998, p.7).

Trazendo essas questões para as artes podemos entender o porquê de, em um primeiro momento, a cultura nativa ter sido duramente achacada e inferiorizada aos olhos da supremacia cultural europeia. Tal se reproduziu em nosso país em diferentes momentos históricos conforme podemos exemplificar através da arte regional, a arte do interior, a arte distante do cânone litorâneo e vista, aos olhos da ortodoxia citadina, como pobre, superficial e pouco adensada em sua estrutura narratológica.

Interessante perceber que hoje (e aqui reforça-se a contribuição da teoria póscolonialista) podemos arrolar, através da leitura de obras literárias consideradas "regionalistas", reflexões sobre a dinâmica maniqueísta imperialista e a aplicação constante do vetor desacreditador na cultura do povo (BONNICI, 1998). Dentre esse arsenal da cultural popular destacam-se as lendas e crenças em "coisas do outro mundo" como pressupostos 
paradigmáticos de forma a contraporem a prepotência imperialista e a exclusão colonialista. Para tal, foram selecionadas as narrativas: "Minha história verdadeira sobre fantasmas", do hindu-americano Rudyard Kipling; e "A madre de ouro", do brasileiro Hugo de Carvalho Ramos, publicadas respectivamente e inicialmente em 1888 e 1917.

Lidas à luz do maquinário gótico, veremos que essas narrativas se interceptam por nos fazerem pensar a respeito de supremacias que se impõem em espaços "dominados" por uma determinada elite (no caso deste trabalho, o despotismo metropolitano), afinal um dos eixos temáticos trabalhados em textos que tematizam o Gótico pauta-se na conflituosa relação entre colônias sob o jugo de suas Metrópoles. Nos contos de Kipling, por exemplo, o medo advindo do contato entre o colonizador inglês e os habitantes das colônias metaforiza a ansiedade britânica ao ver seu domínio sob ameaça de desintegração, numa “[...] clara tradução simbólica na temática que parece dominar a ficção gótica: a natureza do poder, da lei, da sociedade, da família e da sexualidade" (VASCONCELOS, 2002, p. 122), conforme atestaremos.

\section{A queda do Império em Rudyard Kipling e a instauração da República em Hugo de Carvalho}

\section{Ramos}

O eixo cronológico aponta para o fato de que países outrora colonizados, ao adquirirem emancipação política, entrariam no período pós-colonial. Sob essa perspectiva, podemos falar em pós-colonialismo até os dias atuais, não nos permitindo delimitação de uma data final: “Autores tradicionais, definindo pós-colonialismo, usam o termo 'colonial' para descrever o período pré-independência e os termos 'moderno' ou 'recente' para assinalar o período após a emancipação política (BONNICI, 1998, p. 9, grifos do autor)”. Embora o termo pós-colonial seja antigo, somente por volta dos anos de 1980 esse ganha conotações teóricas e amplia seu campo de investigação, passando (ainda que de forma incipiente) a operar uma releitura da colonização orientada para diferentes áreas do conhecimento (estudos culturais, crítica literária, política, história, estudos sociais), sendo ainda essa releitura embasada por críticas às narrativas eurocêntricas - até então vistas como modelo hegemônico de progresso e civilização. Ademais, para além das críticas, os teóricos do pós-colonialismo buscam desconstruir essencialismos e ideias arraigadas que naturalizam e mantêm a inferioridade dos países considerados "excolônias".

Ao aplicarmos a teoria pós-colonialista nas artes, e em especial a arte literária, vemos que duas situações se apresentam: uma se dá quando os críticos passam a conectar textos 
literários dos mais diversos períodos a contextos sociais de opressão (próprios do período colonial e que nos interessa neste trabalho); e a outra situação se dá quando escritores passam a aludir uma escrita genuinamente pós-colonial. Embora sejam situações muito parecidas, a segunda inspira uma certa diferenciação pelo fato de propor, deliberadamente, uma ruptura com o cânone estabelecido, além de fazer emergir textos (muitas vezes rechaçados pela crítica por não primarem pela excelência estética) sublinhados por temáticas demarcadas. Ao optar pela primeira situação, vejo que se trata de uma releitura de obras produzidas e publicadas há mais de um século, no entanto a partir de teorias e concepções pensadas há 40 anos, afinal

\begin{abstract}
A releitura é uma estratégia para reler textos literários ou não-literários e, dessa maneira, garimpar suas implicações imperialistas e trazer à tona o processo colonial. A releitura do texto faz emergir as nuanças coloniais que ele mesmo esconde. Quando se lê um romance da literatura brasileira do século XIX, por exemplo, nada se depara, à primeira vista, sobre os contrapontos da riqueza pessoal dos personagens, da suntuosidade de seus solares e de sua vida folgada. A reinterpretação ou a leitura contrapontual revela que a origem dessa riqueza está enraizada na escravidão de índios e negros, no comércio da carne humana, na invasão e violação de terras alheias, nos castigos horrendos, na manutenção do estado racista. (BONNICI, 2003, p. 216, grifos do autor)
\end{abstract}

Reside, na lógica da releitura, um importante movimento não apenas de esmiuçar os efeitos da colonização e como tais são retratados nas narrativas literárias do período, bem como reinterpretar e desconstruir certas perspectivas textuais obviamente contraditórias em suas conjecturas de raça, religião ou civilização e que tendem a evidenciar os interesses metropolitanos e a ideologia do colonizador. Seleciono, inicialmente, a leitura do conto "Minha história verdadeira sobre fantasmas" de forma a possibilitar uma leitura subversiva dessa lógica (em que o discurso dominante do centro imperial oblitera o discurso periférico), quando, após, farei uma leitura do conto "A madre de ouro".

Nascido em Bombaim, no ano de 1865, Joseph Rudyard Kipling muda-se ainda criança para Inglaterra de onde regressaria para Índia na juventude. Até o ano de sua morte (1936), em Londres, Kipling ainda faria o percurso Índia-Inglaterra inúmeras vezes (com breve passagem pelos Estados Unidos e África do Sul), tendo como principal ofício a escrita (em 1907 Kipling é agraciado com o Nobel de Literatura), além de jornalista e Reitor da Universidade de St. Andrews.

Grande parte da produção de Kipling traz como temática o imperialismo britânico, afinal o escritor vivenciou a chamada era vitoriana (1837-1901), também conhecida como "Era de Ouro" da supremacia inglesa nas colônias - período de intensa industrialização na Inglaterra e ampliação do mercado consumidor. Fazia-se necessária a criação de um aparato ideológico que 
menosprezasse os povos nativos de forma a facilitar a exploração e extração de insumos e matérias-primas a baixo custo, e obviamente esse aparato incluiria construtos preconceituosos e racistas, além de se perpetuar a xenófoba ideia de que os nativos precisavam ter contato com o conhecimento europeu para poderem ascender: "O colonizador, seja espanhol, português, inglês, se impõe como poderoso, civilizado, culto, forte, versado na ciência e na literatura. Por outro lado, o colonizado é descrito constantemente como sem roupa, sem religião, sem lar, sem tecnologia, ou seja, em nível bestial" (BONNICI, 2003, p. 212). Daí que expressões como "raças servis", povos subordinados e inferiores", "terra exótica" tendem a figurar em narrativas literárias do período, conforme podemos notar no conto de Kipling em análise neste trabalho.

Em linhas gerais, o conto "Minha história verdadeira sobre fantasmas" (inserido na coletânea $O$ homem que queria ser Rei e outros contos e publicada inicialmente em 1895) traça as peripécias de um narrador em primeira pessoa em busca de uma história sobre fantasmas. Os primeiros parágrafos da narrativa já nos dão mostras de que o narrador é egresso de outro local: "Existem, nesta terra, fantasmas que tomam a forma de cadáveres gordos e frios e se escondem nas árvores à beira da estrada até que passe um viajante (KIPLING, 2015, p.226)"; e que ocupa uma posição superior: "Seja como for, estes e os fantasmas de cadáveres são artigos nacionais e não atacam sahibs. Nenhum fantasma nativo já foi autenticamente denunciado por ter assustado um cidadão inglês; mas muitos fantasmas ingleses têm assombrado a vida de ambos, brancos ou negros (KIPLING, 2015, p. 226)".

Cabe destacar, nesses dois excertos reproduzidos, que a posição do narrador se alinha com a posição dos representantes do poder metropolitano (viajantes, administradores, soldados, missionários), que tanto enfatizavam a supremacia do centro em detrimento da periferia. A própria descrição de certos locais abriga, nas entrelinhas do discurso e nas escolhas lexicais, o discurso imperial - a palavra indiana sahib, que significa senhor, patrão, superior, era usada por indianos que assim se referiam aos ingleses colonizadores, em total posição de subserviência entre patrão e empregado, o que fica evidente no conto em questão. Ademais, sabemos da posição do narrador-viajante pelo fato de este se hospedar em dâk-bangalôs, alojamentos oficiais construídos pelo governo britânico que sediavam ingleses em "missão" pela Índia: "Nesses dâk-bangalôs, fantasmas são encontrados com mais facilidade, e quando encontrados deve-se tomar nota disso. Há não muito tempo atrás, por motivos profissionais, vivia me hospedando em dâk-bangalôs (KIPLING, 2015, p. 228)".

Conforme a leitura da narrativa se efetua, nota-se a entrada de um novo elemento: a irrupção do medo. O narrador-viajante passa a descrever várias ocorrências de aparições 
fantasmagóricas nas diferentes bases militares em que ele se hospedava, entretanto em nenhuma delas ele consegue atestar a veracidade do que ouvia. Percebe-se, nas diferentes ocorrências que chegam até o rapaz, um misto de incredulidade e ceticismo por parte do mesmo, o que metaforicamente representa a posição metropolitana com relação às suas colônias, afinal o narrador do conto de Kipling, ao não compactuar, em um primeiro momento, com as histórias de fantasmas, nos fornece um subtexto que nos leva às pesquisas de Brantlinger (2013), uma vez que nos "confins do Império" ainda se acreditava no oculto, ao passo que a visão imperial rechaçava tais ideias por pertencerem a uma legião de pessoas ignorantes e atrasadas, conforme notamos no excerto abaixo:

Tendo em vista que parte considerável das tragédias de nossa vida na Índia são encenadas em dâk-bangalôs, fico pensando por que não encontrei nenhum fantasma. Um fantasma que por vontade própria se dependurasse em um dâk-bangalô teria de ser louco, é claro; mas tantos homens morreram loucos nesses lugares que deve haver grande porcentagem de fantasmas lunáticos. (KIPLING, 2015, p.228)

No entanto, o turning point se dá quando o narrador-viajante presencia uma estranha ocorrência em uma noite de pouso em um dâk-bangalô:

No tempo certo encontrei meu fantasma, ou melhor, fantasmas, pois havia dois deles. Até aquele momento eu simpatizava com o método do sr. Besant de lidar com eles, como demonstrado em O estranho caso do sr. Lucraft e outras histórias. Mas agora me oponho. Chamaremos o bangalô de Katmal. Mas esta era a parte menos horrível. Um homem de pele sensível não está apto a dormir em dâk-bangalôs. (KIPLING, 2015, p.228)

Ademais, a chegada do viajante ao local é emoldurada por uma descrição do ambiente típica das narrativas de horror: "Quando cheguei lá, caía uma chuva indecisa e intermitente sobre a face da terra, acompanhada por um vento incessante que a cada rajada fazia um barulho como o chacoalhar de ossos secos nas palmeiras rijas e grudentas do lado de fora" (KIPLING, 2015, p228). Tal fica ainda mais evidente quando o narrador descreve, em pormenores, o interior do local:

Enquanto ele esquartejava o corpo dos animais mortos eu me instalei, após explorar o dâk-bangalô. Havia três quartos além do meu - um canil de esquina - que se comunicavam por entre portas brancas encardidas presas com longas barras de ferro. O bangalô era dos mais sólidos, mas as paredes divisórias dos quartos eram frágeis, feitas com material inferior. Cada passo ou pancada do baú ecoava do meu quarto para os outros três, e cada som de passos voltava com o tremor das paredes distantes. Por essa razão, fechei a porta. Não havia lâmpadas - apenas velas em longos abajures de vidro. Uma lamparina a óleo fora deixada no banheiro. A miséria árida e autêntica daquele dâk-bangalô era a pior de todos em que eu já havia posto os pés. Não havia lareira e as janelas não abriam; por isso não podia acender brasas de carvão. (KIPLING, 2015, p. 229) 
Quando, enfim, o narrador consegue se deitar para dormir, barulhos de carregadores de mala e sons de jogo de bilhar no quarto vizinho ao seu o fazem despertar. Curioso por conta do barulho, o rapaz fixa ainda mais atenção nos passos de seus vizinhos de quarto. A curiosidade dá espaço à instauração do medo, no entanto não "o medo comum de um insulto, injúria ou morte, mas o medo abjeto, o terror palpitante de algo que você não pode ver - medo que resseca o interior da boca e metade da garganta [...]" (KIPLING, 2015, p. 231). Embora ainda um tanto quanto incrédulo, afinal um "homem de pele sensível" não poderia dar anuência à tais ocorrências, o narrador começa a dar os devidos créditos ao fato insólito até que, finalmente, ele próprio atesta a existências de fantasmas.

Importante assinalar que as narrativas de Kipling que trazem irrupção de alguma situação contrária às leias da realidade empírica o fazem não por uma finalidade estética em si e que pretenda induzir o leitor ao medo. Vê-se, destarte, que a instauração do insólito ocorre como uma forma de se lançar críticas às superstições e crenças indianas, e o conto "Minha história verdadeira sobre fantasmas" reforça essa pretensão ao nuançar situações em que o narrador é aterrorizado de forma até mesmo sarcástica, cabendo a este desvendar e resolver a trama fantasmagórica instalada, o que nas entrelinhas nos possibilita ler a metáfora do Império, ou seja, os "fantasmas" podem ser interpretados como o Outro a ser dominado pelo colonizador. Posso ir além ao inferir que em algumas narrativas de Kipling, o narrador se mostra extremamente cético e às vezes até ridiculariza as crenças locais, o que não vemos exatamente em "Minha história verdadeira sobre fantasmas". No conto, o narrador demonstra certa condescendência às ocorrências sobre fantasmas, embora com certo ceticismo e ressalvas, até que ele próprio vivencie a sua história - e, obviamente, na sua posição de alguém egresso da metrópole, a sua história seria a mais importante, se não a única verdadeira, a começar pelo título do conto, "minha história verdadeira".

Essa posição cética do narrador coaduna-se com o momento pelo qual a Índia passava. Vale destacar que Rudyard Kipling vive no país entre os anos de 1884 e 1897, período em que a Índia atravessa um turbulento momento político em prol da emancipação. Kipling, notadamente pró-império, defendia que um país tão diversificado e com grandes proporções geográficas não poderia ser governado de qualquer jeito, a não ser por um império unido (SULLIVAN, 1993), e os indícios fornecidos pela leitura do conto "Minha história verdadeira sobre fantasmas" nos possibilitam essa interpretação. Publicada em 1888, a narrativa traz personagens incapazes de governarem a si mesmos e ainda inseridos em cenários de decadência e abandono numa clara alusão ao posicionamento imperialista de Kipling, ou seja, a 
caracterização de personagens comunica-se com a incapacidade do povo indiano de governar a si próprio aos olhos dos defensores do Império. Natural, para a elite imperialista, que os estereótipos negativos dos indianos fossem ainda mais reforçados nesse momento em que a dominação inglesa estivesse abalada nas colônias, e aqui encontramos eco em narrativas góticas que semiotizam as relações de poder.

Inicialmente ligado a tudo que fosse medieval, pós-romano ou que se referisse à tribo dos godos, o termo Gótico migra para a arquitetura e posteriormente para a literatura imbuído de sentimento de contestação à supremacia neoclássica, além de reagir "[...] às narrativas de progresso e de mudança revolucionária por meio da razão [...] e encenar os medos e temores que rondavam a nascente sociedade burguesa (VASCONCELOS, 2002, p.122)”. Não tardou para que o Gótico fosse adotado como importante veículo para abordar questões políticas e econômicas referentes a um período perturbador e marcado por incertezas de toda ordem, fomentando obras que não apenas expunham as contradições sociais do momento, como atestavam as relações econômicas e políticas entre a decadente aristocracia e a burguesia em ascensão:

Das margens da cultura da Ilustração, dramatizando os conflitos e incertezas diante de um quadro de rápidas mudanças sociais e econômicas, o gótico tornou-se um veículo adequado para tratar das questões políticas e estéticas levantadas pelos acontecimentos na França em 1789. Os ingleses reliam, dessa forma, o espectro da Revolução de 1688 através da Revolução Francesa e deslocavam suas ansiedades para lugares geográfica e temporalmente distantes [...]. (VASCONCELOS, 2002, p.122)

A crítica literária utiliza o termo Gótico como "um termo geral e derrogatório para a Idade Média que conjurava ideias de costumes e práticas bárbaras, de superstição, ignorância, imaginação extravagante e selvageria natural” (BOTTING, 1996, p.15, tradução minha) ${ }^{2}$. Nessa perspectiva, as figuras de monstro da literatura gótica como o vampiro, o lobisomem, os mortosvivos e a própria morte podem ser analisados com relação a sua identificação com grupos excluídos de uma Europa em transição de século.

Tal organicidade encontra-se nos estudos de Patrick Brantlinger (2013), que analisa manifestações muito próprias e pontuais das tradicionais narrativas góticas oitocentistas (que deslindavam, através do medo e terror, os anseios e angústias de uma parcela da população estigmatizada pelas mudanças sociais e econômicas do período), nas narrativas novecentistas que trazem o tema do imperialismo. A esse tipo de literatura, Brantlinger denomina Gótico

\footnotetext{
2 "a general and derogatory term for the Middle Ages which conjured up ideas of barbarous customs and practices, of superstition, ignorance, extravagant fancies and natural wildness.”.
} 
Imperialista, que mantém certos elementos próprios das narrativas góticas tradicionais, como espectros, fantasmas, monstros, temática religiosa, reflexões sobre o poder e o patriarcalismo, porém não mais representando as angústias do homem europeu, mas sim o embate colônia versus metrópole. O que vemos, nas narrativas que emblematizam o Gótico Imperialista, é a perniciosa "transformação" do outro colonizado e não pertencente a elite imperial na monstruosidade a ser temida e evitada. Seguindo essa tendência, as narrativas que possuem como eixo o Gótico Imperialista operam uma combinação por vezes paradoxal, em que a busca por respostas às drásticas mudanças sociais e ao declínio da ortodoxia religiosa poderia levar o colonizador ao mundo oculto que se acreditava existir nas colônias. Isso era algo que os impérios não poderiam admitir, uma vez que práticas bárbaras e ancestrais eram vistas como entrave e ameaça ao progresso, ou seja, as elites temiam que as práticas primitivas, sobrenaturais e milagrosas pudessem "barbarizar" o homem britânico, que deveria, por imposições imperiais, seguir o rumo do progresso:

Os recuos atávicos para o primitivo experimentado por personagens ficcionais parecem frequentemente ser alegorias do movimento regressivo maior da civilização, o progresso britânico transformado em retrocesso britânico. Assim, a primeira parte da fantasia apocalíptica de Richard Jefferies [...] intitula-se "A Recaída na Barbaridade"3. (BRANTLINGER, 2013, p.178, tradução minha)

Vemos que algo parecido com as teorias de Patrick Brantlinger (2013) se opera em nossas narrativas. Conforme o próprio pontua, "Vários romances também apareceram, tanto na Grã-Bretanha e em outros lugares, com títulos ao longo das linhas de declínio e queda do Império Britânico, bem como histórias de invasão da Índia (BRANTLINGER, 2013, p. 181 tradução minha) ${ }^{4}$. Devemos destacar que os avanços do processo industrial, que ganharam ainda mais fôlego na virada do século XIX para o XX, abalariam o poder europeu sobre as colônias em grande parte do continente, daí que podemos elencar uma geração de escritores que não com pouca frequência tematizariam ocorrências como declínio e decadência em suas narrativas. Vemos, também, em grande parte das narrativas produzidas no período, o discurso metropolitano que creditava selvageria, ignorância e atraso às colônias (muito acreditavam, inclusive, que o declínio se devia à presença de nativos e que estes não possuíam o ímpeto necessário para levarem adiante o progresso).

\footnotetext{
3 “The atavistic descents into the primitive experienced by fictional characters seem often to be allegories of the larger regressive movement of civilization, British progress transformed into British backsliding. So the first section of Richard Jefferies's apocalyptic fantasy [...] is entitled "The Relapse into Barbarism”.

4 "Several novels also appeared, both in Britain and elsewhere, with titles along the lines of Decline and Fall of the British Empire, as well as invasion-of-India stories".
} 
No Brasil tivemos um processo de colonização do tipo "colônias de colonizadores" (BONNICI, 2003, p.210), em que uma grande parcela da nossa população nativa foi assassinada e uma modalidade da civilização europeia foi transplantada no vazio construído, ao passo que no caso indiano temos um tipo de "colônias de sociedade invadida", em que o país já possuía organizações societárias, formas políticas e ideologias próprias, porém negligenciadas e ridicularizadas pelos colonizadores (BONNICI, 2003). Esse processo pode explicar, em parte, a ideia que se construiu a respeito do nosso espaço, afinal fomos colonizados, majoritariamente, por um país que tinha os olhos voltados para o mar, daí que antes de se opor à ideia de região colonial, nosso litoral se opunha ao nosso interior.

Partindo dos estudos de Brantlinger (2013), utilizo o termo Gótico Sertanista (CARNEIRO, 2018), que traz em sua composição a ideia de um espaço - o sertão - ameaçador à ordem eurocêntrica vigente. Fomos colonizados, majoritariamente, por um país que tinha os olhos voltados para o mar, daí que antes de se opor à ideia de região colonial, o sertão se opunha ao litoral. O próprio estudo do léxico sertão nos permite antever a ideia de um espaço em total desalinho com a região colonial. Ainda mais significativa é a intenção de se naturalizar a palavra como algo que nos leva a noção de despovoamento, abandono ou o mundo da "des-ordem":

\begin{abstract}
De-Sertum, supino de desere, significa "o que sai da fileira", e passou à linguagem militar para indicar o que deserta, o que sai da ordem, o que desaparece. Daí o substantivo desertanum para indicar o lugar desconhecido onde ia o desertor, facilitando a oposição lugar certo e lugar incerto, desconhecido e, figuradamente, impenetrável. [...] o adjetivo certum através da expressão domicilium certum e da forma que tomou em português arcaico, certão, pode haver contagiado a significação (não a forma) de desertanum como "lugar incerto", sertão, vocábulo que aponta sempre para um sítio oposto e distante de quem está falando. (Teles, apud VICENTINI, 1998, p.45, grifos da autora)
\end{abstract}

Se na narrativa de Kipling acredita-se que o contato com os nativos poderia levar o homem britânico ao regresso e declínio, no Brasil o próprio sertão fomentava na elite metropolitana o medo da decadência, ou seja, o grande espaço desabitado e ermo suscitava o medo do declínio, afinal o referencial era concebido a partir do ponto de vista da supremacia europeia, que avistava, de suas naus, o litoral como sendo "o outro lugar" ou "o lugar do outro", e aqui pontuo os estudos de Alejandra Warwick (1998, p.261-262) que através do termo Colonial Gothic analisa que tanto as pessoas quanto a paisagem são consideradas insólitas aos parâmetros europeus.

Passado o período inicial de colonização, quando os bandeirantes iniciam o processo de exploração rumo ao interior, a visão que os colonizadores tinham em relação ao continente brasileiro se dissemina para o interior, lugar dominado pela natureza e que não poderia se juntar 
ao espaço da civilização litorânea que se formava. Essas considerações podem ser atestadas no pequeno conto "A madre de ouro", que assinala a viagem de um tropeiro pelo interior de Goiás. Aqui também temos a presença de um narrador-viajante que se comove com a cidade que já fora progressista quando recebia egressos do litoral:

\begin{abstract}
Bonfim é uma das cidades mais antigas de Goiás. Como suas irmãs mais velhas, Meia Ponte e Vila Boa de Goiás, guarda ainda, sob muitos aspectos, o cunho dos núcleos coloniais do século XVIII, com a sua inconfundível arquitetura reinol, estilo barroco, de feição pesada, simplória e, ao mesmo tempo que bonachona, hospitaleira - aspecto esse que se vai aos poucos apagando dos burgos e vilórios progressistas mais próximos da linha férrea.

Ficou-lhe, pois, ainda intacto, o antiquado perfume de antanho, coisas mortas que a mente aviva e a tradição redoura, vago encanto do passado, sabor que não têm ou já perderam os centros mercantilistas, tomados de febre de riqueza e inovações, do litoral. (RAMOS, 2003, p. 180)
\end{abstract}

Salienta-se que o conto, "A madre de ouro", faz parte da coletânea Tropas e boiadas, publicada inicialmente em 1917. Nesse período vivenciávamos a Primeira República: rompíamos os laços metropolitanos, assistíamos à queda do Império português, bem como sentíamos os primeiros momentos de ruptura com o cânone europeu. Todo esse sentimento de rupturas e quedas fica ainda mais patente, no conto, conforme o narrador explora o local antes ocupado pela "[...] velha metrópole, já então em via franca de decadência. Hoje, minas, lavras, catas, tudo jaz ao abandono (RAMOS, 2003, p.180)", aproximando o nosso gótico colonial ao gótico imperialista.

Destarte, com a proclamação da República, a intelligentsia brasileira busca novas aspirações ideológicas. As ideias positivistas de Comte, o cientificismo de Darwin e Spencer, o naturalismo de Zola, tornam-se porta-vozes do pensamento republicano que se formava. Há uma passagem na narrativa de Ramos que nos fornece indícios desse pensamento: "Foram-se os antigos bateeiros da descoberta, extinguiu-se a febre da mineração; ficou, enraizada, uma população pacífica e laboriosa, que faz a prosperidade do município na lavoura, na criação do gado, no comércio das letras, em outras profissões liberais (RAMOS, 2003, p. 181)”. Sabemos que migraram para as minas, em grande maioria, portugueses colonizadores que extraíram ouro do interior de Minas Gerias e Goiás. A decadência exposta no conto de Ramos é fruto da exaustão da terra, remexida durante séculos por conta da extração de minérios e, depois, com a economia pecuária. O narrador de Ramos harmoniza-se com a proposta elitista de enaltecer as colônias de europeus que ainda restavam no local, pois acreditava que somente os europeus poderiam proporcionar progresso ao local, o que encontra eco nas ideias imperialistas de 
Kipling quando este apregoa que um país como a Índia precisaria de mãos imperiais para ser governado.

Também no conto de Ramos temos a irrupção de algo insólito, entretanto fazemos algumas ressalvas quanto à posição do narrador. Se na narrativa de Kipling o narrador atesta a veracidade da história fantasmagórica até mesmo como uma forma de controlar a crença no absurdo (lido, metaforicamente como controle do poder imperial que ainda restava nas colônias indianas), em Ramos não verificamos essa dinâmica. Em "A madre de ouro", o narrador assinala que os moradores e alguns viajantes têm "visões" de uma pedra no fundo de um poço, e que esta seria a madre de ouro, "habitante" daquelas águas há muitos anos. Diz a lenda que se um mergulhador tentar furtar o encantado tesouro, a madre o "pune de morte" e entrega o cadáver como refeição para os peixes do lago. O cético narrador dá as devidas explicações racionais para o fato, ao explicar que se trata da lei da refração:

Embalde é a teima, porém, que o mistério do sítio, a profundidade do poço, a refrangência, o desvio de seus raios e momentâneo desaparecimento da visão assim lhe perturbem o imoto cristal, zelam e guardam para sempre inviolada em seu retiro, a pedra maravilhosa. (RAMOS, 2003, p.181)

A narrativa prossegue nesse embate entre as explicações racionais do narrador e a continuidade de se fazer crer na lenda local, conforme podemos atestar na passagem que exibe que se um morador escuta ou vê a passagem da Mãe de Ouro pelo local, deve pegar um pedaço de carvão em brasa e fazer uma cruz de fogo no espaço, que logo a cruz se transforma em ouro maciço. Porém, ao final, vencem as explicações racionais:

História que tem a sua origem nos bólidos, fenômeno que o olhar aparvalhado do matuto observa, muitas vezes, pelas noites claras daquela terra de várzeas e chapadões e de que gera a imaginativa a sua lenda, filha do cósmico deslumbramento e da superstição primitiva. (RAMOS, 2003, p.182)

Se o momento era o de formar uma nação que deveria seguir os rumos do progresso, as crendices e superstições incrustadas nos ermos do sertão deveriam ser rechaçadas pois não compraziam com o modelo de Brasil pré-republicano que se preconizava. Hugo de Carvalho Ramos reforça a postura que a elite imperial e pré-republicana fazia do povo brasileiro. Assim como o Gótico Imperialista, que contrapõe a visão do colonizado à visão do colonizadorimperialista, o Gótico Sertanista analisado em "A madre de ouro" pontua o ideal republicano metaforizado na postura do narrador que, na incerteza entre acreditar ou não nas histórias assombrosas da região, resolve se distanciar com certa apatia dos relatos ouvidos pelos moradores. 
Portanto, o que podemos inferir, com base nos estudos de Brantlinger (2013) é que a organicidade imperialista se mantém. Utilizei, para tal, os estudos sobre o Gótico Imperialista, que aplicados no caso brasileiro nos fazem considerar o Gótico Sertanista como uma releitura das narrativas góticas imperiais, afinal assim como no caso britânico, também no Brasil a elite metropolitana aqui sediada enxergava os centros fornecedores, principalmente o interior e os sertões, como locais não civilizados e atrasados, o que fomentou entre os artistas e intelectuais da época a crença em um espaço habitado por pessoas dadas a práticas bárbaras e retrógradas.

Por fim, ao encararmos a literatura gótica como uma categoria discursiva com a qual podemos, primordialmente, levantar reflexões envolvendo o poder para, então, apregoarmos nossa forma de nomeá-lo: Gótico Sertanista (enquanto termo equivalente ao Gótico Imperialista), o fiz através da leitura de duas narrativas, cujos principais pontos de contato podem ser vislumbrados a seguir (ver Tabela 1): 
Tabela 1: Pontos de contato entre as narrativas de Rudyard Kipling e Hugo de Carvalho Ramos

\begin{tabular}{|c|c|c|c|}
\hline & Espaço & Irrupção do insólito & Narrador \\
\hline \multirow[t]{2}{*}{$\begin{array}{l}\text { "Minha história } \\
\text { verdadeira sobre } \\
\text { fantasmas" } \\
\text { (Gótico imperialista) }\end{array}$} & $\begin{array}{l}\text { A decadência e } \\
\text { abandono marcam o } \\
\text { espaço narratológico. } \\
\text { Tal se alinha com a } \\
\text { decadência vivenciada } \\
\text { pelo Império Britânico } \\
\text { nas colônias indianas. }\end{array}$ & $\begin{array}{l}\text { O insólito irrompe de } \\
\text { forma naturalizada. }\end{array}$ & $\begin{array}{l}\text { O narrador, de patente } \\
\text { militar e egresso da } \\
\text { Metrópole, compactua } \\
\text { com as histórias } \\
\text { fantasmagóricas e } \\
\text { ainda ressalta que tais } \\
\text { fenômenos são } \\
\text { próprios de um local } \\
\text { abandonado, ou seja, o } \\
\text { narrador deveria salvar } \\
\text { os moradores daquelas } \\
\text { ocorrências, numa } \\
\text { clara alusão ao } \\
\text { abandono colonial, em } \\
\text { que somente o Império } \\
\text { poderia salvar os } \\
\text { nativos. }\end{array}$ \\
\hline & Espaço & Irrupção do insólito & Narrador \\
\hline $\begin{array}{l}\text { "A madre de ouro" } \\
\text { (Gótico colonial) }\end{array}$ & $\begin{array}{l}\text { Também marcado pela } \\
\text { decadência, mas com } \\
\text { intenção de se } \\
\text { modernizar por conta } \\
\text { do período republicano } \\
\text { que se instalara } \\
\text { recentemente no país. }\end{array}$ & $\begin{array}{l}\text { O insólito irrompe de } \\
\text { forma ridicularizada, } \\
\text { notadamente marcando } \\
\text { a atraso de um país que } \\
\text { entrava em uma nova } \\
\text { fase, a República. As } \\
\text { superstições deveriam } \\
\text { ser abolidas. }\end{array}$ & $\begin{array}{l}\text { O narrador, também } \\
\text { egresso de outro local, } \\
\text { se mostra cético e ainda } \\
\text { fornece explicações } \\
\text { racionais para a } \\
\text { possível manifestação } \\
\text { de algo irreal, fazendo } \\
\text { alusão ao racionalismo } \\
\text { e cientificismo } \\
\text { vigentes. }\end{array}$ \\
\hline
\end{tabular}

Fonte: A Autora, 2020.

\section{Considerações finais}

Pesa-nos o fato de que transcorridos mais de cinco séculos do período de colonização europeia ao redor do mundo, mantemos as peias de um passado cruel e aviltante. Ainda mais perniciosa torna-se a questão quando percebemos que a rede ideológica colonial se embrenha em direção às regiões distantes do "porto", do litoral, do espaço propriamente receptor das primeiras caravelas em solos africano, asiático e americano e se reproduz na micro-história, nas 
nossas relações diárias, nas nossas interações cotidianas, nas redes sociais, no despretensioso cafezinho da esquina, na "inocente" fala perdoe-me, eu não quis dizer isso.

Buscamos, em nossas pesquisas científicas, o fio do ineditismo, de algo que ainda não fora de todo abordado e que traga contribuições para o meio acadêmico. No entanto, e aqui reforço o corolário dos estudos históricos: “Lembrar para não esquecer”, há que se avultar que ainda que muitas análises já tenham sido levantadas, devemos retomar certos discursos por não terem sido de todo superados - é extenso o caminho a ser percorrido, sempre permeado por nuances ainda não cotejadas ou por falas não totalmente desconstruídas, o que justificou a tessitura deste trabalho.

Após a leitura feita dos contos de Kipling e Ramos, posso inferir que a manifestação de elementos fantasmagóricos ou lendários metaforiza o "último suspiro", ou seja, surge como uma tentativa de manter viva não apenas uma determinada tradição, mas toda uma sociedade que se via à beira do ocaso e prestes a ser subjugada por instâncias mais potentes. Na narrativa de Kipling, o narrador dá crédito aos moradores locais e às suas histórias de fantasmas uma vez que ele se colocaria como o "salvador": se os fantasmas de fato existem, então o narrador, metáfora do Império, poderia livrar aquelas pessoas do perigo, ou seja, a figura do salvador na colônia britânica seria a peça primordial para manutenção do Império britânico. Em Ramos, as lendas são destruídas, "e se alguém escuta ou vê, no ermo da noite, a passagem da mãe de ouro pelo céu [...], deve fazer no espaço uma cruz de fogo" (RAMOS, 2003, p.182), o que, nas entrelinhas, nos aponta para a própria aniquilação da sociedade local, posto que as tradições funcionavam como um entrave à disseminação dos ideais republicanos e progressistas pelo interior do Brasil.

Comprovo, então, que a releitura feita do Gótico Sertanista a partir de concepções do Gótico Imperialista de Patrick Brantlinger (2013) assinala o temor maior do explorador, a saber: a presença de crenças no oculto e no inexplicável impedindo o avanço do "progresso". Tal comprovação se deu com base na teoria pós-colonialista, que ao desconstruir e ressignificar as falas de poder de narrativas antigas, mostra-nos que esquecidos e ridicularizados, os fantasmas falam da própria sociedade nativa/regional, aniquilada em nome do progresso.

\section{REFERÊNCIAS}

BONNICI, Thomas. Pós-colonialismo e representação feminina na literatura pós-colonial em inglês. Acta Scientiarum, v. 28, n. 1, p. 13-25, 2006. Disponível em: www.periodicos.uem.br > index.php > article > download. Acesso em: 10 ago. 2020. 
Teoria e crítica pós-colonialistas. In: BONNICI, Thomas; ZOLIN, Lúcia Osana.

Teoria literária. Abordagens históricas e tendências contemporâneas. Maringá: Eduem, 2003. p. 205-221.

Introdução ao estudo das literaturas pós-coloniais. Mimesis, Bauru, v. 19, n. 1, p. 07 -

23, 1998. Disponível em:

<http://www.usc.br/biblioteca/mimesis/mimesis_v19_n1_1998_art_01.pdf>. Acesso em 16 ago. 2020.

BOTTING, Fred. Gothic. London: Routledge, 1996.

BRANTLINGER, Patrick. Imperial Gothic: Athavism and the Occult in the British Adventure Novel, 1880-1914. In: Rule of Darkness. British Literature and Imperialism, 1830-1914. London: Cornell University Press, 2013. p.176-193.

CARNEIRO, Fabianna Simão Bellizzi. Abjeção, deformidade e canibalismo em "As morféticas" e "A mulher que comeu o amante", de Bernardo Élis. Revista E-scrita, Rio de Janeiro, v. 9, n. 1, p. 82-96, jan./abr. 2018. Disponível em: https://revista.uniabeu.edu.br/index.php/RE/article/view/3200. Acesso em: 21 jan. 2021.

HATTNHER, Álvaro Luiz. Literatura e Estudos Culturais. In: BONNICI, Thomas; ZOLIN, Lúcia Osana (orgs.). Teoria literária: abordagens históricas e tendências contemporâneas. Maringá: Eduem, 2003. p. 249-253.

KIPLING, Rudyard. "Minha história verdadeira sobre fantasmas". In: . O homem que queria ser Rei e outros contos. São Paulo: Landmark, 2015. p. 226-235

RAMOS, Hugo de Carvalho. “A madre de ouro". In: Tropas e boiadas. Rio de Janeiro: Lacerda, 2003. p.180-182.

SULLIVAN, Zohreh T. Narratives of Empire: The Fictions of Rudyard Kipling. Cambridge University Press, 1993.

VASCONCELOS, Sandra Guardini. Dez lições sobre o Romance Inglês do século XVIII. São Paulo: Boitempo Editorial, 2002.

VICENTINI, Albertina. O sertão e a literatura. Sociedade e Cultura, Goiânia, v. 1, n. 1, p.4154, jan./jun. 1998. Disponível em:

https://www.revistas.ufg.br/index.php?journal=fchf\&page=article\&op=view\&path[]=1778. Acesso em: 16 ago. 2020.

WARWICK, Alexandra. Colonial Gothic. In: MULVEY-ROBERTS, Marie. The Handbook to Gothic Literature. New York: New York University Press, 1998, p. 261-262.

Recebido em 29/9/2020.

Aceito em 22/01/2020. 